\title{
Formation of carbonate chimneys in the Mediterranean Sea linked to deep-water oxygen depletion
}

\author{
Germain Bayon ${ }^{1,{ }^{\star}}$, Stéphanie Dupré ${ }^{1}$, Emmanuel Ponzevera ${ }^{1}$, Joël Etoubleau ${ }^{1}$, Sandrine Chéron ${ }^{1}$, \\ Catherine Pierre ${ }^{2}$, Jean Mascle ${ }^{3}$, Antje Boetius ${ }^{4}$, Gert J. de Lange ${ }^{5}$
}

\footnotetext{
${ }^{1}$ IFREMER, Unité de Recherche Géosciences Marines, Brest, France

2 Laboratoire d'Océanographie et du Climat: Expérimentation et Approches Numériques (LOCEAN), UMR 7159, Université Pierre et Marie Curie, Paris, France

${ }^{3}$ Université de Nice Sophia-Antipolis, CNRS, Observatoire de la Côte d'Azur, Géoazur, Villefranche-sur-mer, France

4 HGF-MPG Joint Research Group for Deep Sea Ecology and Technology, Max Planck Institute for Marine Microbiology, Bremen, Germany

${ }^{5}$ Department of Earth Sciences - Geochemistry, Faculty of Geosciences, Utrecht University, The Netherlands
}

\author{
*: Corresponding author : Germain Bayon, tel. 00 33-2-98-22-46-30 ; fax: 00 33-2-98-22-45-70 \\ email address : gbayon@ifremer.fr
}

\begin{abstract}
:
Marine sediments at ocean margins vent substantial amounts of methane $e^{1,2}$. Microbial oxidation of the methane released can trigger the precipitation of carbonate within sediments and support a broad diversity of seafloor ecosystems ${ }^{3,4}$. The factors controlling microbial activity and carbonate precipitation associated with the seepage of submarine fluid over geological time remain poorly constrained. Here, we characterize the petrology and geochemistry of rocks sampled from metre-size build-ups of methane-derived carbonate chimneys located at the Amon mud volcano on the Nile deepsea fan. We find that these carbonates comprise porous structures composed of aggregated spherules of aragonite, and closely resemble microbial carbonate reefs forming at present in the anoxic bottom waters of the Black Sea ${ }^{5}$. Using U-series dating, we show that the Amon carbonate build-ups formed between 12 and 7 thousand years ago, contemporaneous with the deposition of organic-rich sediments in the eastern Mediterranean, the so-called sapropel layer S1. We propose that the onset of deep-water suboxic or anoxic conditions associated with sapropel formation resulted in the development of intense anaerobic microbial activity at the sea floor, and thus the formation of carbonate chimneys.
\end{abstract}

\section{Main}

Fluid venting at methane seeps sustains a broad diversity of ecosystems, which rely on energy derived by chemosynthetic microbes from the oxidation of reduced chemical compounds ${ }^{3}$. The key biogeochemical process in these environments is the anaerobic oxidation of methane, mediated by a consortium of methanotrophic archaea and sulphate-reducing bacteria, which produce dissolved bicarbonate and hydrogen sulphide ${ }^{6}$. At 
cold seeps, AOM typically proceeds in anoxic sub-surface sediments, leading to increased alkalinity levels in pore waters and, as a consequence, often to carbonate precipitation. The occurrence of authigenic carbonate deposits at the seafloor, or in sedimentary records, is therefore often related to the paleoseepage of methane-rich fluids at continental margins. Although microbial activity and carbonate precipitation represent a net sink for methane $\left(\mathrm{CH}_{4}\right)$ at seeps, substantial amounts of $\mathrm{CH}_{4}$ can be expelled into the water column and potentially to the atmosphere ${ }^{1,7}$. Such methane leakage from the ocean represents a potentially important component of the global carbon cycle, and has been linked to past abrupt climate change ${ }^{9}$. However, the processes controlling the activity and variations of cold seeps on continental margins are still insufficiently understood. At a global scale, enhanced fluid flow at continental margins is thought to correlate with periods of low sea-level ${ }^{9,10}$ and, on active margins, with regional tectonic activity ${ }^{11}$.

\section{Large seafloor deposits of authigenic carbonates were discovered recently at Amon MV, on} the Nile deep-sea fan ${ }^{12,13}$ (Fig. 1). Amon is a large, $\sim 3 \mathrm{~km}$ wide, active mud volcano, as indicated by its rough surface morphology, high thermal gradient, presence of gas-charged sediments, dense bacterial mats, and intense emission of hydrocarbon-rich fluids ${ }^{12-15}$. In its western flank, Amon MV is cross-cut by a major linear depression, about 6-10 m deep, which corresponds to the seafloor expression of a deep-seated fault (Fig. 1). The depression is the location of active fluid venting and is filled with reduced sediments associated with bacterial mats of sulfide oxidizers and chemosynthetic tubeworms ${ }^{13,16}$. In the west, the depression is bordered by a large carbonate-paved area, the extent of which can be inferred from the backscatter map derived from a near-bottom high-resolution survey at Amon $\mathrm{MV}^{13}$ (Fig. 1B). While authigenic carbonates within or in the immediate surrounding of the depression correspond to cm-thick slabs or small concretions within the sediment, the deposits 
outcropping west of the depression are typically characterized by meter-tall carbonate buildups (Fig. 2).

We have analysed several carbonate samples recovered from both the depression (carbonate slabs/concretions) and the outcrop area (buildups \#1 to \#4) at Amon MV (Table S1). These samples were collected during the BIONIL cruise in 2006 (R/V Meteor), using a remotely operated vehicle (ROV). The studied carbonate slabs are composed of homogenous microcrystalline cements of mainly high-Mg calcite (BN-122-CC2) and aragonite (BN-122CC3) (Table S2). In contrast, the carbonate outcrops correspond to chimney-like buildups with prominent protuberances that are sometimes pierced with cm-size holes (Fig. 2C). The outcrops are coated with a thin layer of black $(\mathrm{Mn})$ and orange $(\mathrm{Fe})$ oxyhydroxides. The outer surface of the buildups corresponds primarily to microcrystalline aragonite and high-Mg calcite cement (Fig. 2C; Fig. 3). In contrast, their hollow interior part is mainly composed of mm-size aragonite spherules covered with aragonite needles (Fig. 2C). The very negative carbon isotopic compositions $\left(\delta^{13} \mathrm{C}\right)$ of the bulk carbonate samples (from -40.2 to $-26.8 \%$ VPDB; Table S3) clearly indicate that Amon slabs and chimneys both derive from the microbial oxidation of hydrocarbon-rich fluids.

The carbonate buildups discovered at Amon MV resemble in macro- and microscale morphology the microbial carbonate deposits that form at present in the anoxic waters of the Black Sea ${ }^{5,17-19}$. Many of the large carbonate-paved areas at submarine seepage sites are thought to have been exposed on the seafloor after initial formation within anoxic sub-surface sediments, in response to e.g. sediment winnowing, erosion by bottom currents ${ }^{20}$, or sediment instability ${ }^{21}$. This is because oxidation of methane-rich fluids in oxic bottom waters usually prevents carbonate precipitation due to release of dissolved $\mathrm{CO}_{2}$ and decreasing $\mathrm{pH}$. One 
notable exception is the occurrence of chemoherm structures that may grow into oxic bottom waters at highly active seepage sites $^{22}$, such as the Hydrate Ridge ${ }^{23}$. These chemoherms typically form large carbonate mounds up to 30-meter high that are covered by microbial mats, which sustain local anoxic conditions at the seawater-carbonate interface. When seepage occurs in an anoxic marine environment, however, anaerobic microbial activity and subsequent carbonate precipitation can extend more freely into bottom waters. In the anoxic waters of the Black Sea, microbial communities form nodular structures at the seafloor that progressively calcify as they grow upward within the water column ${ }^{24}$. This can lead to the formation of chimney-like edifices, with holes through which gas bubble streams escape that closely resemble those observed at Amon MV (Fig. 2C). Such carbonate buildups associated with living microbial mats are currently only known from the anoxic Black Sea.

The carbonate slabs at Amon MV display carbonate contents typically below < 89 wt\%, which reflect the presence of an additional detrital sedimentary component. In contrast, the chimney samples are composed almost exclusively of pure carbonate (mean value: $96.7 \pm 2.2$ wt\%; Table S2). This suggests that while the thin carbonate slabs probably formed within sub-surface sediments at Amon MV, the overlying carbonate edifices most likely developed above the seafloor, similar to what can be observed in the Black Sea at present. Among the other similarities observed between the Amon and Black Sea carbonate buildups, both appear to be anchored on spherical disc-shaped carbonate plates at the seafloor (Fig. 2A/B; ref. 18). In the Black Sea, the inside structures of the microbial reefs typically correspond to spongelike porous carbonates ${ }^{17,18}$, which form irregular cavities similar to those described at Amon MV (Fig. 2C). The calcification processes described in the anoxic Black Sea also produce spherical crystal aggregates ${ }^{18,19}$, similar to the yellowish aragonite cement described above for the Amon buildups (Fig. 2C). 
The age of the studied carbonate precipitates was determined using U/Th dating techniques $^{25}$ (Table 1). The carbonate slab BN-122-CC3 is the most recent, $~ 1.3$ ka (thousand years before present). This corresponds with it being collected from within the depression, i.e. the most active present-day seepage area in southwestern Amon MV (Fig. 1). Despite the relatively large uncertainties in the age of some samples (Table 1), our U/Th data indicate that all other Amon MV carbonate buildups formed between about 12 and 7 thousand years ago. In detail, there is significant age heterogeneity at the buildup/sample scale. For example, the age for the outer part of sample BN-122-CC4 (buildup \#1) appears to be older ( 11 to $10 \mathrm{ka}$ ) than that for its inner part ( 9 to $7.5 \mathrm{ka}$; Fig. 3). This observation provides evidence for a nearly continuous period of carbonate buildup formation.

The time interval of carbonate buildup formation at Amon MV appears thus to be largely contemporaneous with the formation of the most recent Mediterranean sapropel S1 $(\sim 6-11$ $\mathrm{ka}^{26}$ ). Sapropel intervals correspond to the deposition of organic-rich sediments in the eastern Mediterranean Sea. The high $\mathrm{C}_{\text {org }}$ contents in sapropel layers (i.e. typically higher than 2 wt\%) are a consequence of both high marine productivity and enhanced preservation due to bottom-water anoxia ${ }^{26,27}$. It is generally assumed that the onset of anoxia in eastern Mediterranean deep waters at that time was related to intensifying monsoon rainfall in East Africa, leading in turn to enhanced freshwater discharge from the Nile River and water column stratification in the eastern Mediterranean Sea ${ }^{27}$. While the general water column oxic/anoxic boundary was located around 1800 meter-depth during the sapropel period ${ }^{26}$, oxygen depletion also occurred at intermediate water depth $(\sim 900 / 1200 \mathrm{~m})$ in the southeastern Mediterranean. This is supported by micropaleontological investigations, which indicate that benthic ecosystems collapsed in this area at the onset of sapropel S1 (ref. 28). 
The rare earth element composition of Amon carbonates also provides information on bottomwater redox conditions at the time of carbonate precipitation. The Amon buildups exhibit Ceanomalies ranging from 0.63 to 0.91 (see Table S4), higher than values for cold seep carbonates formed under oxic conditions (Ce/Ce* $~ 0.2-0.5)$, but similar to those collected from the oxygen-depleted environments of the Black Sea ${ }^{29}$ (see Supplementary Information). Considering all the above, therefore, this suggests that suboxic/anoxic conditions also prevailed in bottom waters at Amon MV during the sapropel time interval.

Over geological time, fluid seepage at Amon MV has probably been mainly driven by density gradients and fluid-sediment interactions deep within the volcano’s plumbing system. On shorter timescales (thousands of years), however, our results suggest that variation of the dissolved oxygen contents of bottom waters played a role in controlling sub-surface microbial activity patterns and related carbonate precipitation. Under oxic conditions (i.e. at present; $\mathrm{O}_{2}$ bottom water content of $\sim 200 \mu \mathrm{M}^{16}$ ), anaerobic microbial activity is restricted to within the sub-surface seafloor of the Amon MV, where flat carbonate slabs or concretions form, fed by methane leakage pathways from deep subsurface reservoirs. Instead, during sapropel S1, the shift towards suboxic/anoxic bottom-water conditions probably allowed development of anaerobic microbial communities at the seafloor. At that time, the deposition of large amounts of freshly deposited organic material and associated microbial degradation may have also led to higher rates of methanogenesis in surface sediments, enhancing anaerobic methanotrophy and sulphate reduction. Consequently, the methane oxidation front must have migrated from near-surface sediments to overlying bottom waters, thereby supporting the growth of carbonate chimneys into the water column. After about four thousand years of near-continuous activity, microbial methane turnover in bottom waters ended with the complete re-oxygenation of the deep eastern Mediterranean basin at 6 ka (ref. 26). 
The link that we have identified between seawater dissolved $\mathrm{O}_{2}$ and the activity of subseafloor microbial communities at Amon MV may yield further insight into the significance of cold seeps to the global carbon cycle. It was recently proposed that the production of methane-derived carbonates in marine sediments increased during periods of widespread oceanic anoxia, acting as a major carbon sink in the geological past ${ }^{30}$. To date, however, clear evidence for enhanced authigenic carbonate precipitation in ancient anoxic oceans is still lacking from the geological record. In this context, the Amon MV chimneys hence probably represent a first fossil example of cold seep carbonate deposits formed within oxygendepleted deep waters. On the basis of our results, it is also possible that an enhanced methane flux would reach the bottom water during an anoxic episode of sapropel formation. Concordingly, similar enhanced methane fluxes may have occurred repeatedly in ancient oceans at oxygen minimum zones on margins, and possibly during periods of Black Shales formation. This could not only have had an impact on sub-seafloor anaerobic microbial activity at cold seeps, but potentially also on atmosphere-arriving methane fluxes, thus on the marine and global carbon cycle.

\section{METHODS}

\section{Mineralogy}

Bulk carbonate samples were washed using ultrapure water, dried, and then crushed in an agate mortar. The total carbonate content was determined by automatic calcimetry, with an estimated error of $<4 \%$ (Table S2). The bulk mineralogy of the carbonate samples was also characterized by X-ray diffraction (Brüker D8 Advance). Bulk mineralogical abundances were calculated using TOPAS Rietveld analysis (Table S2). 


\section{Major element and stable isotope compositions}

The bulk major element and stable isotope compositions were determined by wavelengthdispersive X-ray fluorescence (WD-XRF, Brüker S8 Tiger) and dual-inlet isotopic ratio mass spectrometry (DI-IRMS Isoprime), respectively (Table S3). Isotopic compositions are reported in conventional delta $(\delta)$ units relative to the Vienna Peedee Belemnite reference (VPDB).

\section{Trace element analyses}

About 5 mg of ground bulk carbonate powder were digested with 5\% (v/v) acetic acid. Rare earth and other trace element concentrations were measured with an Element 2 ICP-SFMS at the Pôle Spectrométrie Océan (Brest). The REE and other trace element data are reported in Table S4 and briefly discussed below in the Supplementary Information text.

\section{Chemical procedures and mass spectrometry}

Polished sections of each carbonate sample were examined by optical microscopy to select sampling areas suitable for uranium-thorium dating, based on the mineralogy and texture of carbonate growth. For each U-Th measurement, 1-12 mg of carbonate powder were collected using a MicroMill system (New Wave Research). A mixed ${ }^{236} \mathrm{U} /{ }^{229}$ Th spike was added to each carbonate sample, prior to digestion on hotplate using concentrated $\mathrm{HNO}_{3}$ : $\mathrm{HCl}$ (aqua regia). Any remaining detrital residue was digested in $\mathrm{HF}: \mathrm{HCl}$ on hotplate. $\mathrm{U}$ and Th were purified from the bulk carbonate matrix after Fe-oxyhydroxide co-precipitation and chemical separation using anion exchange method ${ }^{25}$. The total procedural blanks were negligible compared to total sample size. $\mathrm{U}$ and Th concentrations and isotopic ratios were determined 
at the Pôle Spectrométrie Océan (Brest) with a Neptune MC-ICP-MS coupled with an APEX desolvating nebulizer. Measured isotopic ratios were corrected from mass discrimination with a standard-bracketing protocol, using IRMM-184 and IRMM-035 standard solutions for $\mathrm{U}$ and Th, respectively. Internal precision obtained on measured ${ }^{234} \mathrm{U} /{ }^{238} \mathrm{U}$ and ${ }^{229} \mathrm{Th} /{ }^{230} \mathrm{Th}$ ratios were generally better than $3 \%$ and 50\%o, respectively. Measured $U$ and Th concentrations and isotopic compositions are listed in Table S5.

\section{U/Th dating using isochron methods}

Because cold seep carbonate crusts typically contain substantial amounts of clays and other sedimentary components that are included during the carbonate cementation, isochron methods are often required to correct measured U-Th isotope ratios from detrital contamination and calculate carbonate $\operatorname{age}^{25}$. The activity ratios used for calculating carbonate ages are listed in Table S6. Isochron calculations were performed using the ISOPLOT program (v. 3.71). A two-point isochron approach was used to date the samples, considering a theoretical sediment end-member at secular equilibrium (activity ratios $=1.0 \pm$ 0.5). This end-member was assumed to be representative of the detrital fraction incorporated by the carbonate samples. Initially, several sediment samples collected during previous cruises at Amon MV were analysed to determine experimentally the detrital end-member required for isochron calculations. These samples were first digested by alkaline fusion, after spike addition, and then processed using the same procedure described above for carbonate samples. However, these sediments exhibited relatively high $\left({ }^{238} \mathrm{U} /{ }^{232} \mathrm{Th}\right)$ activity ratios (from about 2 to 25; Table S5), suggesting the presence of dispersed authigenic carbonate phases in the sediment (Fig. S1). For this reason, we decided to correct obtained carbonate ages from detrital contamination using a theoretical end-member at secular equilibrium. Note however that the isochron ages calculated with our theoretical end-member agree well (within 20\%) 
with those inferred from the experimental end-member. In addition, for two carbonate buildups (\#1 and \#3), we also calculated a mean formation age using a conventional isochron approach, i.e. assuming that all the sub-samples for each of the two buildups had precipitated at the same time. The mean formation age inferred from this conventional isochron approach for buildups \#1 and \#3 was $7.9 \pm 1.4$ and $6.3 \pm 0.7 \mathrm{ka}$, respectively (Fig. S1). These ages agree relatively well with the two-point isochron ages calculated using a theoretical endmember, thereby providing further support for their significance. To a large extent, the associated age uncertainties are dependent on the measured $\left({ }^{230} \mathrm{Th} /{ }^{232} \mathrm{Th}\right)$ ratios, ranging from 1\% (BN-122-CC4-4) to 69 \% (BN-122-CC3-2). An 'in-house' standard (NL7-CC2; a cold seep carbonate crust from the Central Province of the Nile deep-sea $\operatorname{fan}^{25}$ ) was analysed repeatedly during the course of this project, which gave an average U/Th age of $1570 \pm 380 \mathrm{yr}$ (2 SD; $n=9$ ). The associated uncertainty ( $\pm 24 \%$ ) can be taken as an estimate of the external reproducibility on the U/Th ages reported in Table 1.

\section{REFERENCES CITED}

1. Solomon, E. A., Kastner, M., MacDonald, I. R. \& Leifer, I. Considerable methane fluxes to the atmosphere from hydrocarbon seeps in the Gulf of Mexico. Nature Geosci. 2, 561-565 (2009).

2. Westbrook, G. K., et al. Escape of methane gas from the seabed along the West Spitsbergen continental margin. Geophys. Res. Lett. 36, L15608, doi:10.1029/2009GL039191 (2009).

3. Sibuet, M. \& Olu, K. Biogeography, biodiversity and fluid dependence of deep-sea cold-seep communities at active and passive margins. Deep-Sea Res. II 45, 517-567 (1998). 
4. Pohlman, J. W., Bauer, J. E., Waite, W. F., Osburn, C. L. \& Chapman, N. R. Methane hydrate-bearing seeps as a source of aged dissolved organic carbon to the oceans. Nature Geosci. 4, 37-41 (2011).

5. Michaelis, W. et al. Microbial reefs in the Black Sea fueled by anaerobic oxidation of methane. Science 297, 1013-1015 (2002).

6. Boetius, A. et al. A marine microbial consortium apparently mediating anaerobic oxidation of methane. Nature 407, 623-626 (2000).

7. Etiope, G., \& Milkov, A. A new estimate of global methane flux from onshore and shallow submarine mud volcanoes to the atmosphere: Environ. Geol. 46, 997-1002 (2004).

8. Cohen, A. S., Coe, A. L. \& Kemp, D. B. The late Palaeocene-Early Eocene and Toarcian (Early Jurassic) carbon isotope excursions: a comparison of their time scales, associated environmental changes, causes and consequences. J. Geol. Soc. 164, 10931108 (2007).

9. Teichert, B. M. A. et al. U/Th systematics and ages of authigenic carbonates from Hydrate Ridge, Cascadia Margin: Recorders of fluid flow variations. Geochim. Cosmochim. Acta 67, 3845-3857 (2003).

10. Kiel, S. Global hydrocarbon seep-carbonate precipitation correlates with deep-water temperatures and eustatic sea-level fluctuations since the Late Jurassic. Terra Nova 21, 279-284 (2009).

11. Kutterolf, S. et al. Lifetime and cyclicity of fluid venting at forearc mound structures determined by tephrostratigraphy and radiometric dating of authigenic carbonates. Geology 36, 707-710 (2008). 
12. Dupre, S. et al. High-resolution mapping of large gas emitting mud volcanoes on the Egyptian continental margin (Nile Deep Sea Fan) by AUV surveys. Mar. Geophys. Res. 29, 275-290 (2008).

13. Dupre, S. et al. Seafloor geological studies above active gas chimneys off Egypt (Central Nile deep sea fan). Deep Sea Res. I 54, 1146-1172 (2007).

14. Dupre, S., Woodside, J., Klaucke, I., Mascle, J. \& Foucher, J.-P. Widespread active seepage activity on the Nile Deep Sea Fan (offshore Egypt) revealed by highdefinition geophysical imagery. Mar. Geol. 275, 1-19 (2010).

15. Mastalerz, V., de Lange, G. J. \& Dahlmann, A. Differential aerobic and anaerobic oxidation of hydrocarbon gases discharged at mud volcanoes in the Nile deep-sea fan. Geochim. Cosmochim. Acta 73, 3849-3863 (2009).

16. Girnth, A. C. et al. A novel mat-forming Thiomargarita population associated with a sulfidic fluid flow from a deep-sea mud volcano. Environ. Microbiol. 13, 495-505 (2011).

17. Treude, T. et al. Consumption of methane and $\mathrm{CO}_{2}$ by methanotrophic microbial mats from gas seeps of the anoxic Black Sea. Appl. Environ. Microbiol. 73, 2271-2283 (2007).

18. Reitner, J., Peckmann, J., Reimer, A., Schumann, G. \& Thiel, V. Methane-derived carbonate build-ups and associated microbial communities at cold seeps on the lower Crimean shelf (Black Sea). Facies 51, 66-79 (2005).

19. Bahr, A. et al. Authigenic carbonate precipitates from the NE Black Sea: a mineralogical, geochemical, and lipid miomarker study. Int. J. Earth Sci. 98, 677-695 (2009).

20. Naehr, T. H. et al. Authigenic carbonate formation at hydrocarbon seeps in continental margin sediments: A comparative study. Deep Sea Res. II 54, 1268-1291 (2007). 
21. Bayon, G. et al. Multi-disciplinary investigation of fluid seepage on an unstable margin: The case of the Central Nile deep sea fan. Mar. Geol. 261, 92-104 (2009).

22. Luff, R., Wallmann, K. \& Aloisi, G. Physical and biogeochemical constraints on carbonate crust formation at cold vent sites: significance for fluid and methane budgets and chemosynthetic biological communities. Earth Planet. Sci. Lett. 221, 337-353 (2004).

23. Teichert, B. M. A., Bohrmann, G. \& Suess, E. Chemoherms on Hydrate Ridge Unique microbially-mediated carbonate build-ups growing into the water column. Palaeogeog., Palaeoclimatol., Palaeoecol. 227, 67-85 (2005).

24. Treude, T., Knittel, K., Blumenberg, M., Seifert, R. \& Boetius, A. Subsurface microbial methanotrophic mats in the Black Sea. Appl. Environ. Microbiol. 71, 63756378 (2005).

25. Bayon, G., Henderson, G. M. \& Bohn, M. U-Th stratigraphy of a cold seep carbonate crust. Chem. Geol. 260, 47-56 (2009).

26. De Lange, G. J. et al. Synchronous basin-wide formation and redox-controlled preservation of a Mediterranean sapropel. Nature Geosci. 1, 606-610 (2008).

27. Rohling, E. J. Review and new aspects concerning the formation of eastern Mediterranean sapropels. Mar. Geol. 122, 1-28 (1994).

28. Schmiedl et al. Climatic forcing of eastern Mediterranean deep-water formation and benthic ecosystems during the past 22000 years. Quat. Sci. Rev.29, 3006-3020 (2010).

29. Feng, D., Lin, Z. J., Bian, Y. Y., Chen, D. F., Peckmann, J., Bohrmann, G. \& Roberts, H. H. Rare earth elements of seep carbonates: Indication for redox variations and microbiological processes at modern seep sites. J. Asian Earth Sci. 65, 27-33 (2013).

30. Schrag,D. P., Higgins, J. A., Macdonald, F. A. \& Johnston, D. T. Authigenic carbonate and the history of the global carbon cycle. Science 339, 540-543 (2013). 
Correspondence and requests for materials should be addressed to Germain Bayon.

\section{ACKNOWLEDGEMENTS}

We thank the crews of R/V Meteor and ROV QUEST4000 (MARUM, University of Bremen, Germany), and all participants of the BIONIL cruise (M70/2; chief scientist: A. Boetius) for their assistance at sea. We acknowledge Y. Germain, E. Rongemaille, A. Roubi, C. Bassoullet for help in the laboratory at IFREMER and Institut Universitaire Européen de la Mer (I.U.E.M.), respectively. We are very grateful to G.M. Henderson for providing the UTh spike, and also thank A. Crémière, E. Ducassou, J.-P. Foucher, T. Himmler, and V. Liebetrau for helpful discussions. Three anonymous reviewers are also thanked for their insightful comments on this manuscript. This work was funded via the ESF EUROCORES project MEDIFLUX, the EU $6^{\text {th }}$ FP HERMES project (GOCE-CT-2005-511234-1), the EU $7^{\text {th }}$ FP HERMIONE project (contract 226354), and IFREMER.

\section{AUTHOR CONTRIBUTIONS}

G.B., S.D., J.M. and A.B conceived the project and participated in the BIONIL cruise (R/V Meteor). G.B. performed sample/chemical preparation, and wrote the article. G.B., E.P., J.E., S.C. and C.P. analysed the samples. All authors contributed to discussions, interpretation of the results and manuscript writing.

\section{FIGURE CAPTIONS}

Figure 1. Bathymetric map of Amon MV and location of studied carbonate samples. A. High-resolution shaded bathymetry map. Acoustic evidence for gas bubble emissions in the 
water column at Amon MV are shown in red. The open square represents the inset of the backscatter map (Fig. 1B). B. 3D view of the southwestern flank of Amon MV, with highresolution backscatter draped on the bathymetry. The highly backscattering area (in white) characterizes the extent of sub-seafloor authigenic carbonates. Yellow patches indicate the location of studied carbonate samples. The black thick lines correspond to the bathymetric profiles in the lower panels.

Figure 2. Amon MV carbonate chimneys. A,B. Seafloor bottom photographs of Amon MV carbonate deposits. Buildups \#1 (A) and \#4 (B). The chimneys are characterized by prominent protuberances pierced with cm-size holes (fossil fluid conduits) and covered by Fe(orange) and/or Mn- (black) oxyhydroxides. The arrows represent the location of the samples collected with the ROV QUEST4000 during the BIONIL cruise. C. Zoom-in of the carbonate buildup \#1. The hollow interior part of the carbonate chimney is composed of mm-size aragonite spherules covered with aragonite needles, which represent fossil analogs of the modern microbial reefs from the Black Sea (anoxic environment).

Figure 3. U/Th ages for selected polished sections (buildup \#1). The filled (green) squares indicate the areas sampled for U/Th measurements (sample BN-122-CC4). The age for the outer part of sample BN-122-CC4 is older ( 11 to 10 kyr BP) than that for its inner part ( 9 to 7.5 kyr BP). 

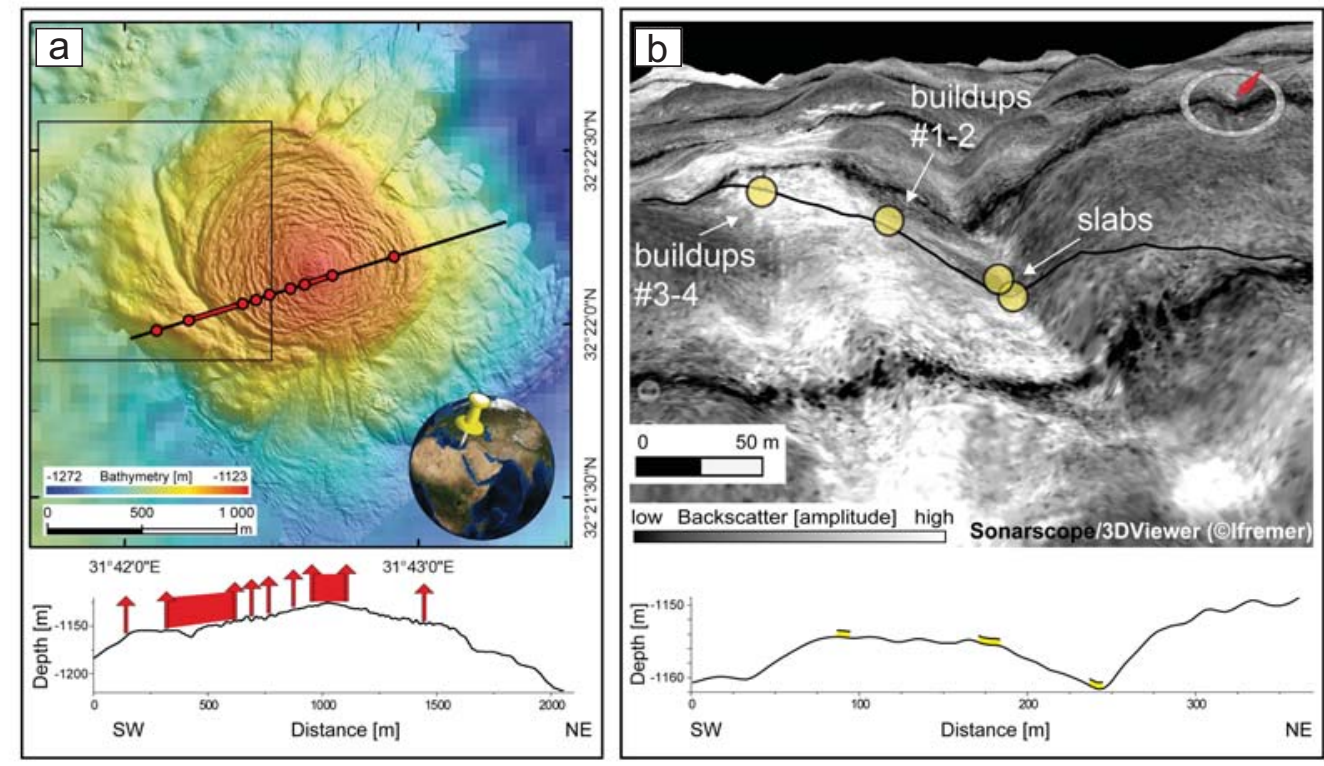


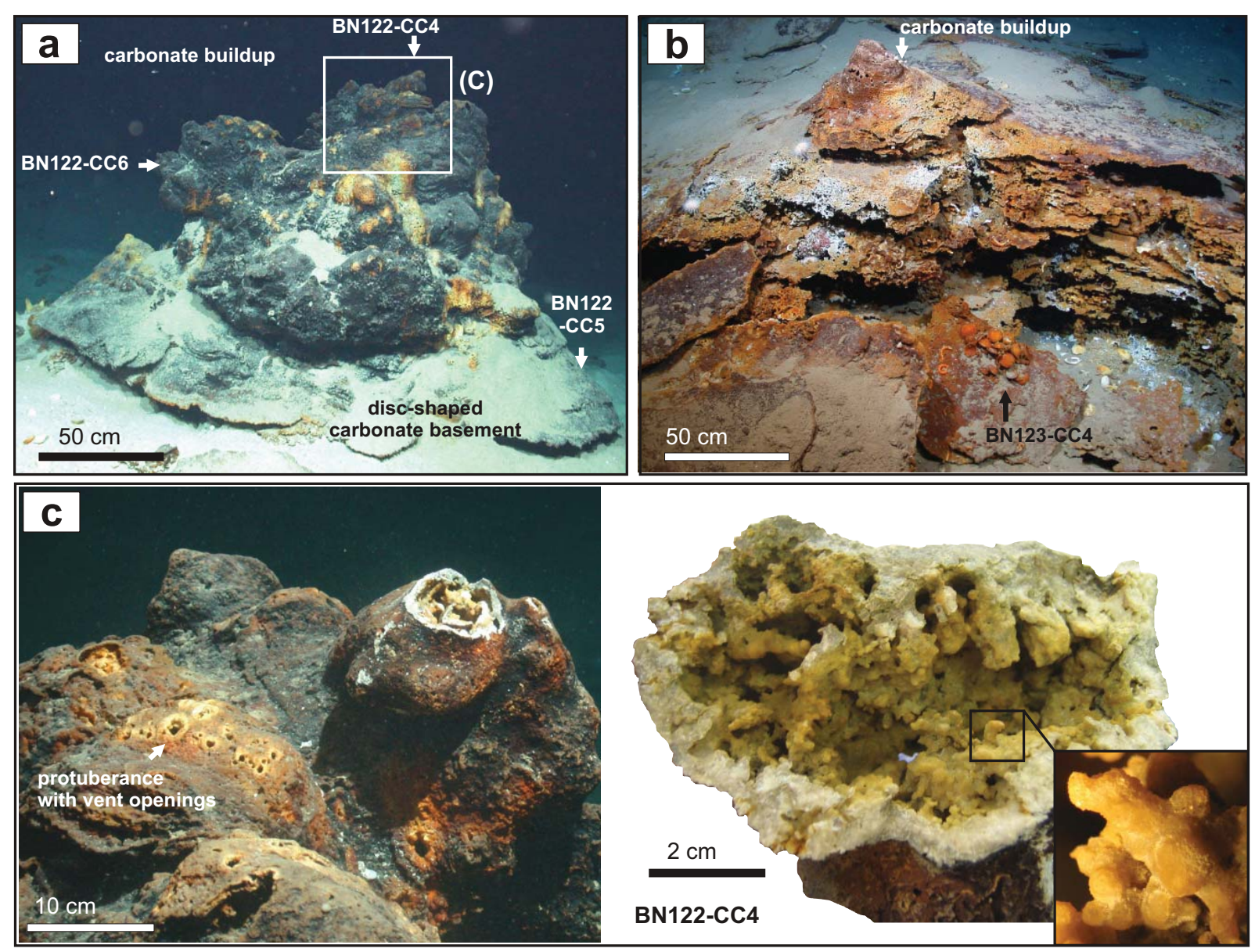




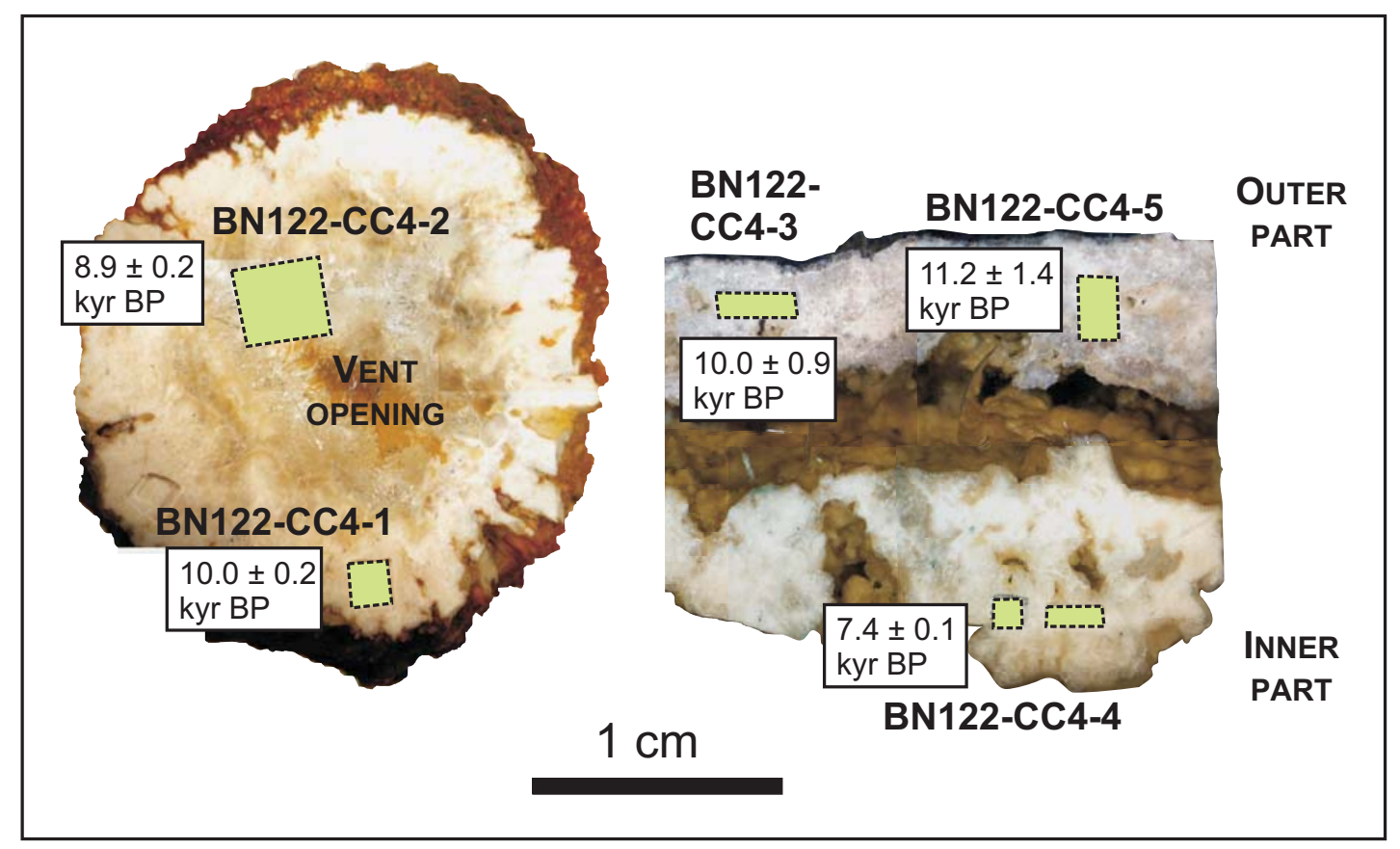

Fig. 3 
Table 1. U-Th isotope data and calculated isochron ages for AMON MV carbonate samples

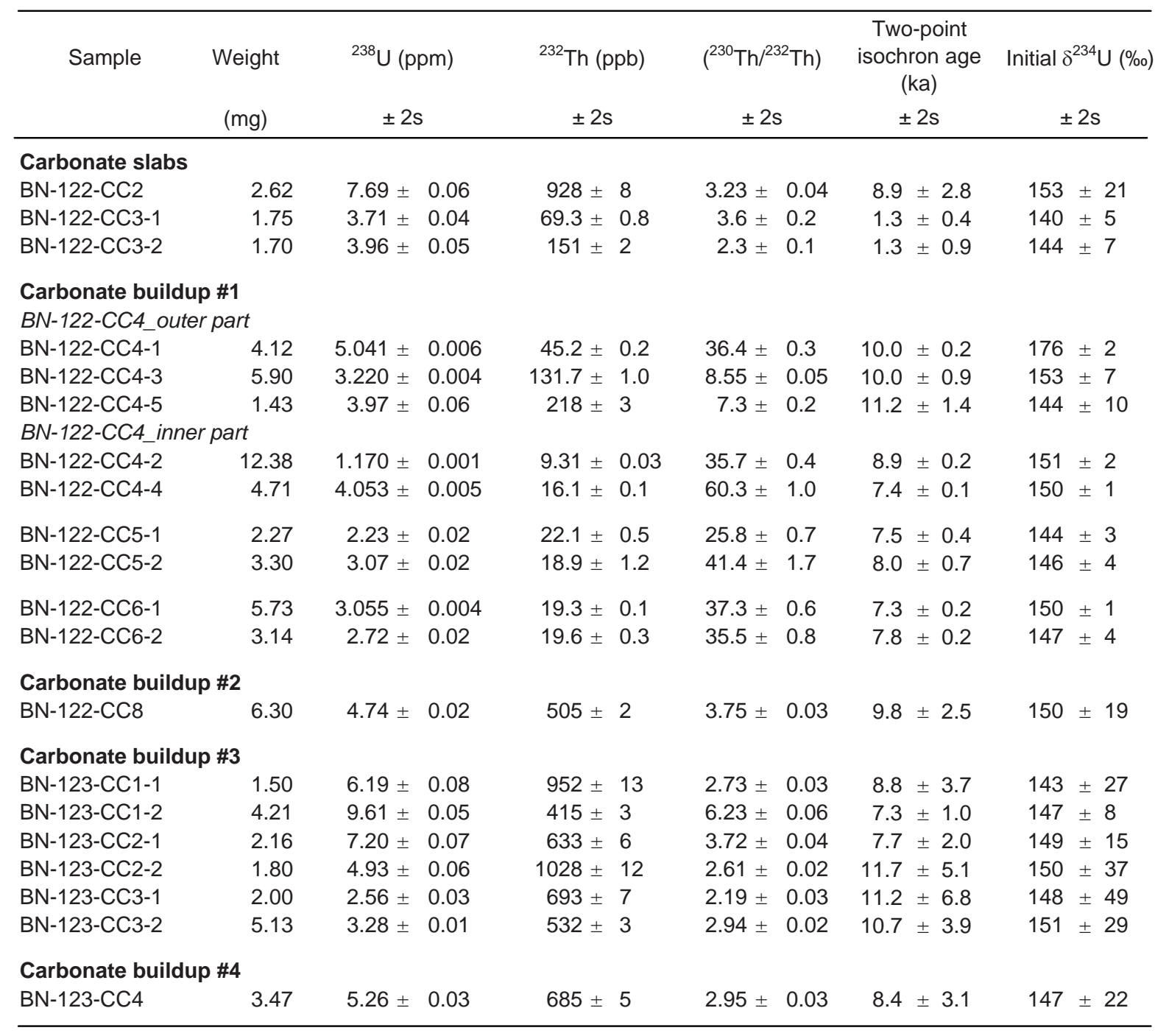

Initial $\delta^{234} U$ represents the deviation in permil of $\left({ }^{234} U /{ }^{238} U\right)$ from its secular equilibrium value of 1.000 , at the time $T$ of carbonate precipiation, with Initial $\left.\delta^{234} U=\left[\left\{\left({ }^{234} U /{ }^{238} U\right)_{T} /\left({ }^{234} U /{ }^{238} U\right)\right)_{\text {equ }}\right\}-1\right] \times 10^{3}$.

Measured values are corrected for detrital contamination and decay of excess ${ }^{234} U$ since sample formation. 